\title{
Synthesis of pyridyl substituted pyrazolo[4,3-c]pyridines as potential inhibitors of protein kinases
}

\author{
Gytė Vilkauskaitė, ${ }^{a, b}$ Patricia Schaaf, ${ }^{a}$ Algirdas Šačkus, ${ }^{b}$ Vladimir Krystof ${ }^{c_{*}}$ \\ and Wolfgang Holzer ${ }^{a} *$ \\ ${ }^{a}$ Department of Drug and Natural Product Synthesis, Faculty of Life Sciences, \\ University of Vienna, Althanstrasse 14, A-1090 Vienna, Austria \\ ${ }^{b}$ Institute of Synthetic Chemistry, Kaunas University of Technology, \\ Radvilenu pl. 19, 50254 Kaunas, Lithuania \\ ${ }^{c}$ Laboratory of Growth Regulators, Faculty of Science, Palacky University \\ and Institute of Experimental Botany ASCR, \\ Slechtitelu 11, 78371 Olomouc, Czech Republic. \\ E-mail: wolfgang.holzer@univie.ac.at, vladimir.krystof@upol.cz

\section{Dedicated with our best wishes to Prof. Dr. Rosa Maria Claramunt on the occasion of her $65^{\text {th }}$ birthday}

\begin{abstract}
A synthetic route towards 3-(2-pyridyl)-6-(hetero)aryl-1 $H$-pyrazolo[4,3-c]pyridines is described. The key step consists of a microwave-assisted multi-component reaction, including a Sonogashira type cross-coupling of appropriate 5-chloropyrazole-4-carbaldehydes with alkynyl(hetero)arenes followed by pyridine ring formation of the coupling products in the presence of tert-butylamine, directly affording the title compounds. A congener without substituent at N-1 was accessed via cleavage of a tert-butyl protecting group. Detailed NMR spectroscopic studies $\left({ }^{1} \mathrm{H},{ }^{13} \mathrm{C}\right.$ and $\left.{ }^{15} \mathrm{~N}\right)$ were undertaken with the obtained compounds. Selected representatives were evaluated for their potential as inhibitors of protein kinases.
\end{abstract}

Keywords: Pyrazolones; Sonogashira reaction; multi-component reactions; fused pyrazoles, pyridines; cyclin-dependent kinase (CDK) inhibitors; ${ }^{15} \mathrm{~N}$ NMR spectroscopy

\section{Introduction}

Cyclin-dependent protein kinases (CDKs) are import drug targets with regard to the treatment of proliferative diseases such as cancer and inflammation. ${ }^{1-3}$ Thus, in the last years considerable effort has been devoted to the development of small molecule inhibitors of CDKs as potential 
drug candidates for oncology. ${ }^{1,2,4}$ The purine system became one of the first systematically investigated scaffolds for CDK inhibitors, leading to the discovery of roscovitine (Figure 1), which represents one of the first candidates to enter clinical trials. ${ }^{5-7}$ Naturally, the latter compound has inspired further exploration of new CDK inhibitors by variation of the substituents and by repositioning of nitrogen atoms on the purine scaffold. Thus, various congeners containing 2-5 nitrogen atoms in the bicyclic core have been considered. In the course of these investigations, representatives of four classes of bioisosteres revealed improved biological properties, namely pyrazolo[4,3- $d$ ]pyrimidines (A), pyrazolo[1,5- $a$ ]pyrimidines (B), pyrazolo[1,5-a]pyridines (C) and pyrazolo[1,5-a][1,3,5]triazines (D) (Figure 1). ${ }^{8,9}$ In view of this we became interested in somewhat related compounds of type $\mathbf{E}$, characterized by a pyrazolo[4,3-c]pyridine core and carrying at least one pyridyl substituent in order to provide a slightly basic side-chain (Figure 1).

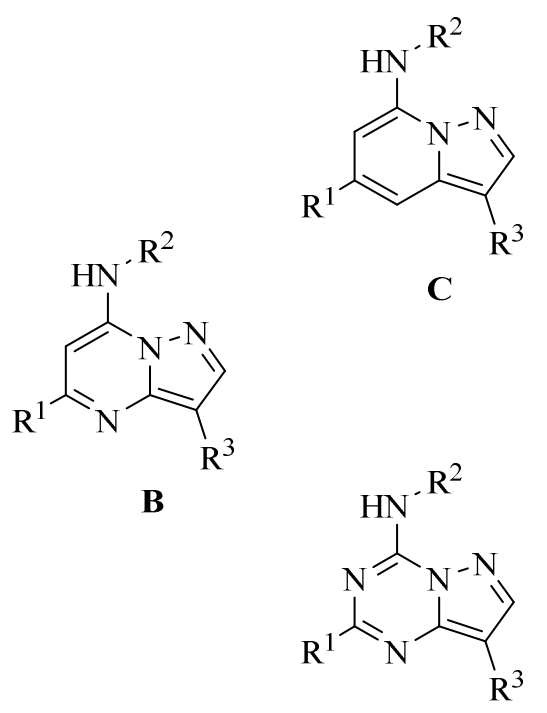

D

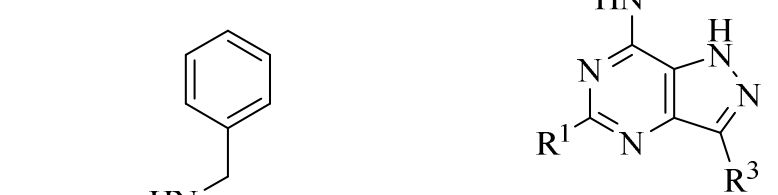

$\mathbf{A}$

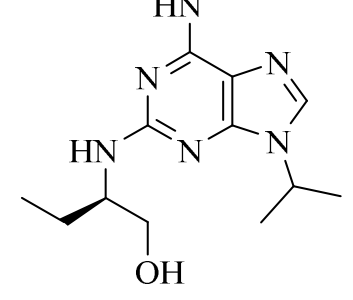

roscovitine

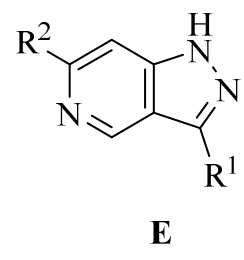

$\mathrm{R}^{1}=$ 2-pyridinyl, $\mathrm{R}^{2}=$ (hetero)aryl

Figure 1. Roscovitine and related systems as (potential) CDK inhibitors.

\section{Results and Discussion}

\section{Synthetic study}

Recently, we have presented a novel and general access to the synthesis of pyrazolo[4,3-c]pyridines via Sonogashira cross-coupling of 5-chloropyrazole-4-carbaldehydes and subsequent pyridine ring closure of the resulting 5-alkynylpyrazole-4-carbaldehydes in the presence of tertbutylamine as the nitrogen source. ${ }^{10}$ According to this approach, the envisaged synthetic pathway to the target compounds of type $\mathbf{6}$ and 7, respectively, is presented in Scheme 1. $\beta$-Keto ester 2, obtained via condensation of 2-acetylpyridine (1) with diethyl carbonate, should be transformed 
into the appropriate pyrazolone $\mathbf{3}$ and the latter by Vilsmeier reaction - with concomitant transformation of the $\mathrm{OH}$ group into a chloro functionality - into the corresponding $N$-protected 5-chloropyrazole-4-carbaldehyde 4. Subsequently, Sonogashira coupling reaction with terminal alkynes should generate the respective alkyne intermediate 5, which in the presence of tertbutylamine should undergo ring closure into the respective pyrazolo[4,3-c]pyridine 6. Optional removal of the protecting $\mathrm{R}^{1}$ should provide congeners of type 7 unsubstituted at pyrazole $\mathrm{N}-1$.
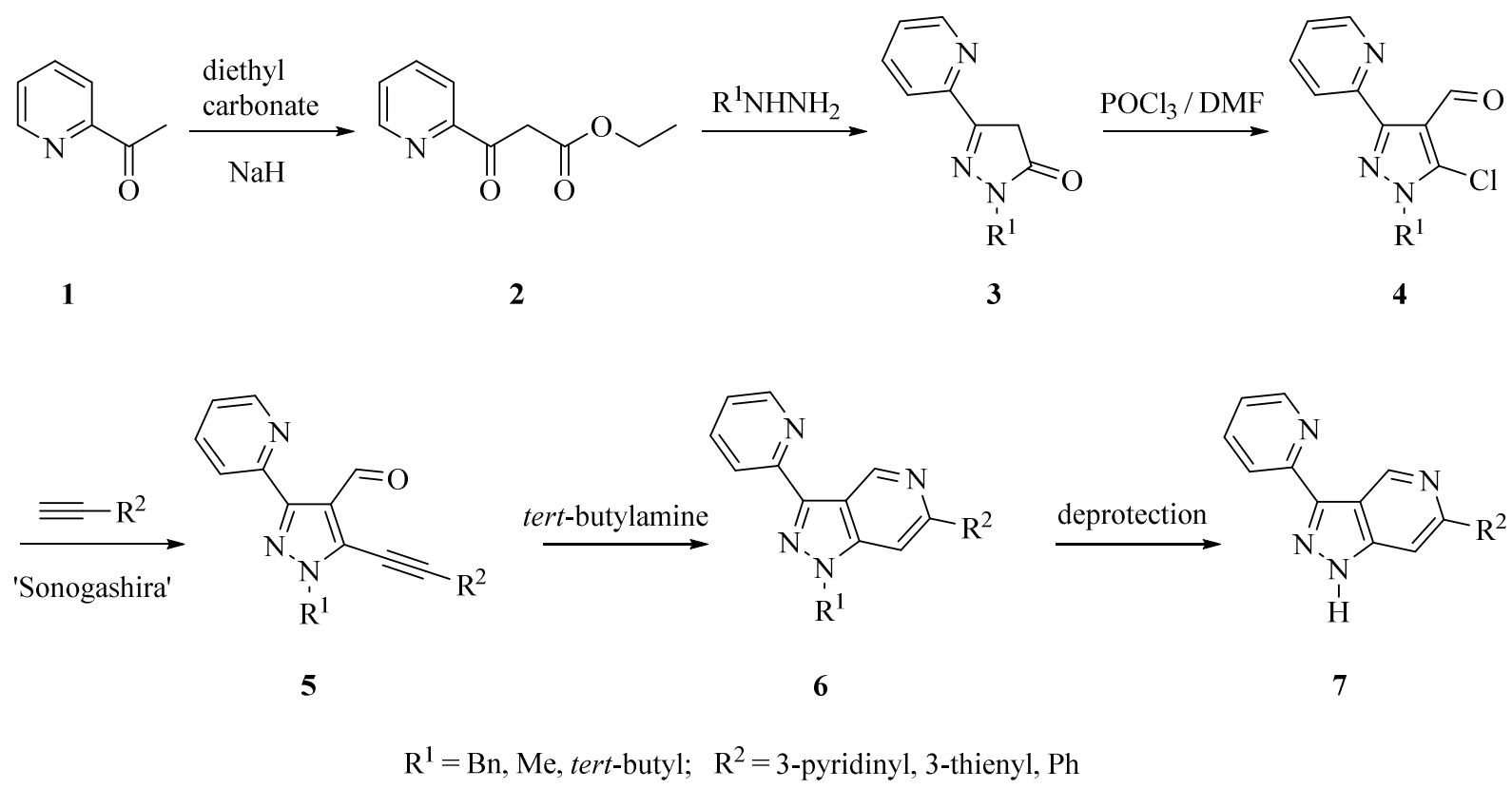

Scheme 1. Envisaged synthetic route to the target compounds 6 and 7.

Initially, employment of a para-methoxybenzyl (PMB) protecting group $\left(\mathrm{R}^{1}=\mathrm{PMB}\right)$ was considered for further procedure, because PMB is an approved protecting group for pyrazoles and condensed pyrazoles, and several examples show more or less uncomplicated cleavage by treatment with TFA. ${ }^{11-13}$ Unfortunately, an orienting Vilsmeier-Haak formylation ${ }^{14}$ applied to 2(4-methoxybenzyl)-2,4-dihydro-3H-pyrazol-3-one demonstrated that the PMB group does not survive the harsh conditions of this reaction. For this reason, the more stable but harder to cleave benzyl group and the even less vulnerable methyl group were considered as possible $\mathrm{R}^{1}$ protecting groups. The synthesis of pyrazolones $\mathbf{3}\left(\mathbf{3 a}: \mathrm{R}^{1}=\mathrm{Me}, \mathbf{3 b} \cdot \mathrm{R}^{1}=\mathrm{PhCH}_{2}\right)$ was accomplished via reaction of 3-oxoester $\mathbf{2}$ - the latter obtained by condensation of 2-acetylpyridine (1) with diethyl carbonate - with methylhydrazine and benzylhydrazine, respectively. The high electron density at position 4 of the pyrazole system of compounds 3a,b permits smooth Vilsmeier-Haack formylation $\left(\mathrm{DMF} / \mathrm{POCl}_{3}\right)$, whereas due to the presence of excessive $\mathrm{POCl}_{3}$ the $\mathrm{OH}$-group (the tautomeric equivalent of pyrazolone $\mathrm{C}=\mathrm{O}$ ) is simultaneously transformed into a chloro function to afford 5-chloropyrazole-4-carbaldehydes $\mathbf{4 a , b}$ in good yields. ${ }^{15}$ In recent studies we have shown that 1 -substituted 5-chloropyrazole-4-carbaldehydes 
are suitable reactants in Sonogashira cross-coupling reactions with appropriate alkynes. ${ }^{10,16}$ Although the general order of reactivity for substrates is known to be R-I > R-Br $\sim$ R-OTf > $\mathrm{R}-\mathrm{Cl},{ }^{17}$ the activated chloro atom in the latter turned out to be a good leaving group. Surprisingly, aldehydes $\mathbf{4 a , b}$ proved to be fairly inert in cross-couplings with phenylacetylene or 2-ethynylpyridine under standard conditions. Neither did variation of the Pd catalyst and/or solvent, nor applying the reaction under microwave assistance, lead to satisfying results, i.e. to the formation of coupling products $\mathbf{5}$ in acceptable yields. However, a breakthrough was achieved when Sonogashira coupling and subsequent pyridine ring closure to bicycles $\mathbf{6}$ were carried out as a one-pot multi-component reaction. Thus, microwave heating $\left(800 \mathrm{~W}, 150{ }^{\circ} \mathrm{C}\right.$, 1h) of aldehydes 4 with an alkyne and excessive tert-butylamine in DMF in the presence of $\mathrm{PdCl}_{2}\left(\mathrm{PPh}_{3}\right)_{2}$ afforded pyrazolopyridines 6a-d in acceptable to good yields (Scheme 2). It should be emphasized that in recent years such multi-component reactions (MCRs) have attracted considerable attention due to their unmatched synthetic efficiency which permits the construction of complex molecules in an elegant and sufficient manner. ${ }^{18,19}$

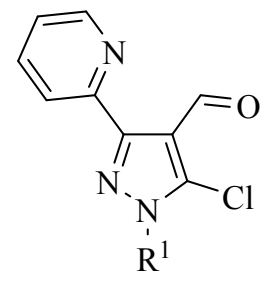

4

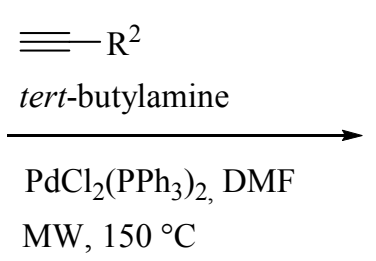

MW, $150^{\circ} \mathrm{C}$

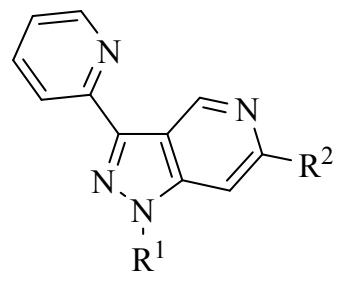

6

\begin{tabular}{l|l|l}
$\mathbf{6}$ & $\mathrm{R}^{1}$ & \multicolumn{1}{|c}{$\mathrm{R}^{2}$} \\
\hline $\mathbf{a}$ & $\mathrm{Me}$ & $\mathrm{Ph}$ \\
$\mathbf{b}$ & $\mathrm{Me}$ & 2-pyridinyl \\
$\mathbf{c}$ & $\mathrm{Me}$ & 3-pyridinyl \\
$\mathbf{d}$ & $\mathrm{Bn}$ & 3-pyridinyl \\
$\mathbf{e}$ & tert-Bu & 3-pyridinyl \\
$\mathbf{f}$ & tert-Bu & 3-thienyl
\end{tabular}

$\mathrm{H}_{2} \mathrm{SO}_{4}$ conc.

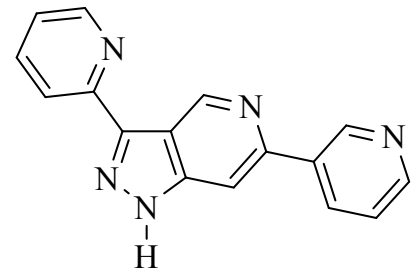

$7 \mathbf{a}$

Scheme 2. Synthesis of pyrazolo[4,3-c]pyridines 6a-f and 7a.

In order to prepare $N$-unsubstituted congeners, for instance 7a, which could be used in biological tests, removal of the $\mathrm{N}-1$ protecting group in the corresponding compounds $\mathbf{6}$ was necessary. It is known from the literature that $N$-methyl groups can be removed from $\mathrm{N}-1$ of pyrazoles or condensed pyrazoles by melting the $N$-methyl derivatives with anhydrous pyridine hydrochloride. ${ }^{20}$ However, when compounds 6a-c were subjected to such reaction conditions $\left(210{ }^{\circ} \mathrm{C}\right)$ in most cases complex reaction mixtures resulting from decomposition reactions were 
obtained. Removal of the benzyl group of $\mathbf{6 d}$ was attempted by various hydrogenolytic methods $\left(\mathrm{Pd} / \mathrm{C}\right.$ or $\mathrm{Pd}(\mathrm{OH})_{2} /$ formic acid / ammonium formate; $\mathrm{Pd} / \mathrm{C}, \mathrm{H}_{2}, \mathrm{MeOH} ; \mathrm{Pd} / \mathrm{C}, 1$,4-cyclohexadiene, EtOH). ${ }^{21-23}$ Either unreacted starting material was obtained or decomposition was observed. As benzylic protecting groups alternatively can be removed by oxidative methods, also the system $\mathrm{KO} t$ - $\mathrm{Bu} / \mathrm{DMSO}^{24}$ was applied, but no reaction was observed. Furthermore, treatment with TFA, $\mathrm{HBr}$ or $\mathrm{AlCl}_{3}$ in toluene was not successful. As an alternative, the tert-butyl protecting group was considered; this has been successfully employed in pyrazole chemistry. ${ }^{25}$ Thus, pyrazolone 3c $\left(\mathrm{R}^{1}=\right.$ tert-butyl) was prepared from $\mathbf{2}$ and tert-butylhydrazine and subsequently converted into aldehyde $\mathbf{4 c}\left(\mathrm{R}^{1}=\right.$ tert-butyl, Scheme 1$)$, however in low yields. Multi-component reaction with 3-alkynylpyridine or 3-alkynylthiophene, respectively, afforded bicycles $\mathbf{6 e}$ and $\mathbf{6 f}$. The deprotection of $6 \mathbf{e}$ was tried under different conditions, for instance in TFA, TFA- $\mathrm{H}_{2} \mathrm{O}$ ( $\mathrm{rt}$ and afterwards at $120{ }^{\circ} \mathrm{C}$ ), as well in $\mathrm{HCOOH}, \mathrm{HCl}$, at $\mathrm{rt}$ and reflux, where no reaction was observed. Finally, the removal of the protecting group was accomplished by treatment of $\mathbf{6 e}$ with conc. $\mathrm{H}_{2} \mathrm{SO}_{4}$ affording the target compound $7 \mathbf{a}$ (Scheme 2).

\section{NMR Spectroscopic investigations}

Pyrazolones of type $\mathbf{3}$ are capable of prototropic tautomerism. ${ }^{26,27}$ Discounting participation of the pyridine system in the tautomerism, in principle three different tautomeric forms are possible, i.e. the $\mathrm{OH}(\mathbf{A})$, the $\mathrm{CH}(\mathbf{B})$ and the $\mathrm{NH}$ form (C) (Figure 2, upper row). The ${ }^{1} \mathrm{H}$ and the ${ }^{13} \mathrm{C}$ NMR spectra of pyrazolones $\mathbf{3 a}\left(\mathrm{R}^{1}=\mathrm{Me}\right), \mathbf{3 b}\left(\mathrm{R}^{1}=\mathrm{PhCH}_{2}\right)$ and $\mathbf{3 c}\left(\mathrm{R}^{1}=\right.$ tert-butyl $)$ clearly show that these compounds are exclusively present as $\mathrm{CH}$-isomers $\mathbf{B}$ in $\mathrm{CDCl}_{3}$ solution due to the appearance of a $\mathrm{CH}_{2}$ fragment at position 4 of the pyrazole ring (for instance $3 \mathbf{b}:{ }^{1} \mathrm{H}: 3.81$ ppm, $2 \mathrm{H}$; corresponding ${ }^{13} \mathrm{C}$ : $38.2 \mathrm{ppm}, \mathrm{CH}_{2}$ multiplicity according to APT; Figure 2, lower row, left).

Because pyrazolone $\mathbf{3 b}$ showed limited solubility in $\mathrm{CDCl}_{3}$, spectra were also taken of a DMSO- $d_{6}$ solution. In the latter solvent, $\mathbf{3 b}$ turned out to exist as 5-hydroxypyrazole (form $\mathbf{A}$ ), as confirmed by the appearance of pyrazole $\mathrm{C}-4$ as $\mathrm{CH}$-fragment $\left({ }^{1} \mathrm{H}: 5.98 \mathrm{ppm},{ }^{13} \mathrm{C}: 84.5 \mathrm{ppm}\right)$, the ${ }^{13} \mathrm{C}$ chemical shift of pyrazole C-5 (153.2 ppm) and particularly by the ${ }^{15} \mathrm{~N}$ chemical shift of N-2 $(-102.2)$ ppm (Figure 2, lower row, right), the latter definitely ruling out the $\mathrm{NH}$-form $\mathbf{C}$.

Due to the low solubility of 7a in chloroform the NMR spectra were recorded of a DMSO- $d_{6}$ solution. In principle, for $\mathbf{7 a}$ annular prototropic tautomerism at the pyrazole ring is possible (proton attached to $\mathrm{N}-1$ or $\mathrm{N}-2$ ). Moreover, the flexible proton theoretically could be also located at N-5 or at the pyridine $\mathrm{N}$-atom of the 3-substituent, however the latter possibilities can be definitely ruled out considering the ${ }^{15} \mathrm{~N}$ chemical shifts of the concerning nitrogen atoms. Nevertheless, a distinct NOE between the acidic proton ( $\delta 13.89 \mathrm{ppm})$ and $\mathrm{H}-7$ ( $\delta \quad 8.17 \mathrm{ppm}$ ) unequivocally confirms preference for the N1-H form (Figure 3, right). Moreover, the similarity of ${ }^{1} \mathrm{H},{ }^{13} \mathrm{C}$ and ${ }^{15} \mathrm{~N}$ NMR chemical shifts of $7 \mathbf{a}$ with those of the 'fixed' $N$-methyl congener $\mathbf{6 c}$ (Figure 3, left) strongly confirms this assignment. 


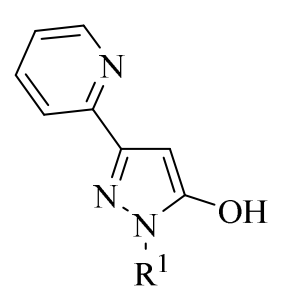

A

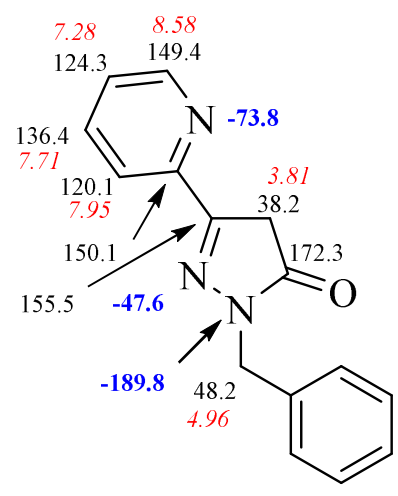

$\mathbf{3 b}\left(\mathrm{CDCl}_{3}\right)$

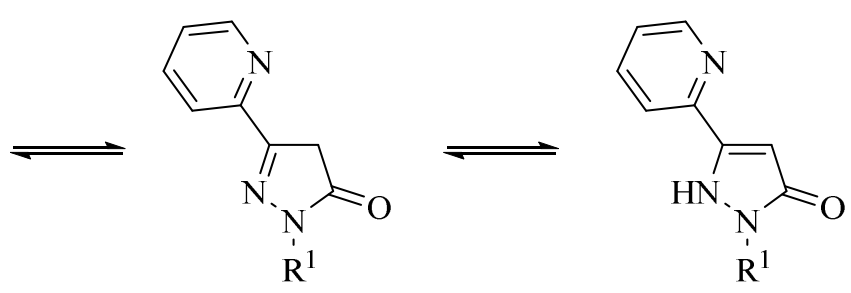

$\mathbf{B}$

C

\section{3}

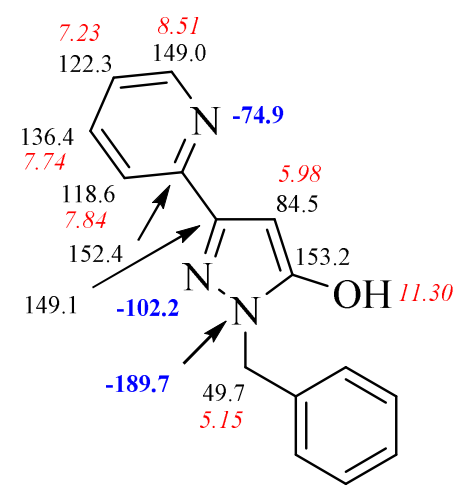

3b (DMSO- $\left.d_{6}\right)$

Figure 2. Upper row: tautomeric forms of pyrazolones 3; lower row: selected ${ }^{1} \mathrm{H}$ (italics, red), ${ }^{13} \mathrm{C}$ and ${ }^{15} \mathrm{~N}$ NMR (bold, blue) chemical shifts of $\mathbf{3 b}$ in $\mathrm{CDCl}_{3}$ and DMSO- $d_{6}$ solution.

Because pyrazolone 3b showed limited solubility in $\mathrm{CDCl}_{3}$, spectra were also taken of a DMSO- $d_{6}$ solution. In the latter solvent, $\mathbf{3 b}$ turned out to exist as 5-hydroxypyrazole (form $\mathbf{A}$ ), as confirmed by the appearance of pyrazole $\mathrm{C}-4$ as $\mathrm{CH}$-fragment $\left({ }^{1} \mathrm{H}: 5.98 \mathrm{ppm},{ }^{13} \mathrm{C}: 84.5 \mathrm{ppm}\right)$, the ${ }^{13} \mathrm{C}$ chemical shift of pyrazole $\mathrm{C}-5(153.2 \mathrm{ppm})$ and particularly by the ${ }^{15} \mathrm{~N}$ chemical shift of N-2 (-102.2) ppm (Figure 2, lower row, right), the latter definitely ruling out the NH-form $\mathbf{C}$.

Due to the low solubility of 7a in chloroform the NMR spectra were recorded of a DMSO- $d_{6}$ solution. In principle, for $\mathbf{7 a}$ annular prototropic tautomerism at the pyrazole ring is possible (proton attached to $\mathrm{N}-1$ or $\mathrm{N}-2$ ). Moreover, the flexible proton theoretically could be also located at $\mathrm{N}-5$ or at the pyridine $\mathrm{N}$-atom of the 3 -substituent, however the latter possibilities can be definitely ruled out considering the ${ }^{15} \mathrm{~N}$ chemical shifts of the concerning nitrogen atoms. Nevertheless, a distinct NOE between the acidic proton ( $\delta 13.89 \mathrm{ppm})$ and $\mathrm{H}-7$ ( $\delta 8.17 \mathrm{ppm})$ unequivocally confirms preference for the N1-H form (Figure 3, right). Moreover, the similarity of ${ }^{1} \mathrm{H},{ }^{13} \mathrm{C}$ and ${ }^{15} \mathrm{~N}$ NMR chemical shifts of $7 \mathbf{a}$ with those of the 'fixed' $N$-methyl congener $\mathbf{6 c}$ (Figure 3, left) strongly confirms this assignment. 


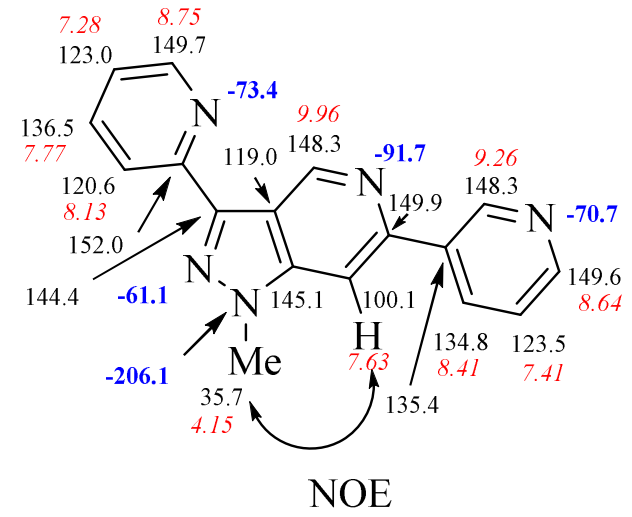

$\mathbf{6 c}\left(\mathrm{CDCl}_{3}\right)$

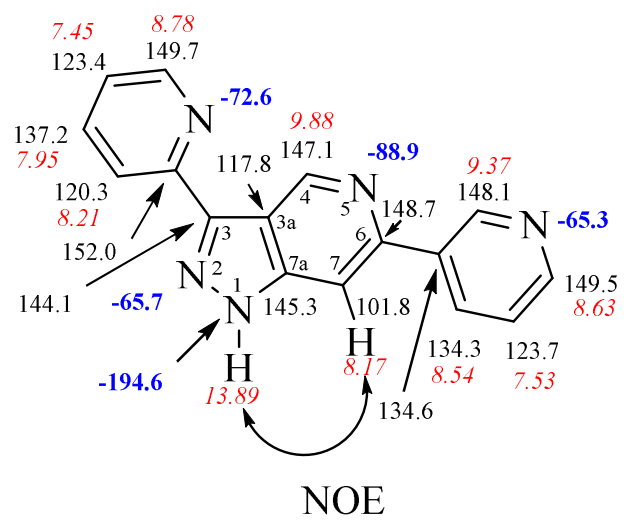

$7 \mathbf{a}\left(\mathrm{DMSO}-d_{6}\right)$

Figure 3. ${ }^{1} \mathrm{H}$ (italics, red), ${ }^{13} \mathrm{C}$ and ${ }^{15} \mathrm{~N}$ NMR (bold, blue) chemical shifts for compounds $\mathbf{6 c}$ and 7a.

\section{Biological tests}

Our aim was to prepare a new scaffold of protein kinase inhibitors. Therefore, the biological activity of prepared compounds 6 and 7 was assayed as described previously. ${ }^{28}$ The compounds have been tested in kinase inhibition assays for their inhibitory potency towards recombinant CDK2, CDK9, CK2 and c-Abl, and for their cytotoxicity against various cancer cell lines. None of the tested compounds proved biological activity, but we consider these results to be preliminary and further modification of the molecules are necessary to identify first hits amongst our pyrazolo[4,3-c]pyridines. Most known kinase inhibitors are heterocyclic organic molecules that act like ATP competitors, interacting through one to three hydrogen bonds with the hinge region of the kinase. ${ }^{1}$ Our future work will focus on modifications that would create typical Hbond donor-acceptor motif and on modifications increasing the polarity (solubility).

\section{Experimental Section}

General. Melting points were determined with a Reichert-Kofler hot-stage microscope. Mass spectra were obtained on a Shimadzu GP 1000 instrument (EI, $70 \mathrm{eV}$ ), a Bruker maXis 4G instrument (ESI-TOF, HRMS) and a Finnigan MAT 8230 instrument (EI, $70 \mathrm{eV}, \mathrm{HRMS}) .{ }^{1} \mathrm{H}$, ${ }^{13} \mathrm{C}$ and ${ }^{15} \mathrm{~N}$ NMR spectra were recorded with a Bruker Avance III 400 spectrometer at $293 \mathrm{~K}$ (400 MHz for ${ }^{1} \mathrm{H}, 100 \mathrm{MHz}$ for ${ }^{13} \mathrm{C}, 40 \mathrm{MHz}$ for ${ }^{15} \mathrm{~N}$ ). The center of the solvent signal was used as an internal standard which was related to TMS with $\delta \quad 7.26 \mathrm{ppm}\left({ }^{1} \mathrm{H}\right.$ in $\left.\mathrm{CDCl}_{3}\right), \delta 2.49 \mathrm{ppm}$ $\left({ }^{1} \mathrm{H}\right.$ in DMSO- $\left.d_{6}\right), \delta 77.0 \mathrm{ppm}\left({ }^{13} \mathrm{C}\right.$ in $\left.\mathrm{CDCl}_{3}\right), \delta 39.5 \mathrm{ppm}\left({ }^{13} \mathrm{C}\right.$ in DMSO- $\left.d_{6}\right) .{ }^{15} \mathrm{~N}$ NMR spectra (gs-HMBC, gs-HSQC) (40.56 MHz) were obtained using a "directly" detecting broadband 
observe (BBFO) probe were referenced against neat, external nitromethane. Digital resolutions were $0.25 \mathrm{~Hz}$ /data point in the ${ }^{1} \mathrm{H}$ and $0.4 \mathrm{~Hz} /$ data point in the ${ }^{1} \mathrm{H}$-coupled ${ }^{13} \mathrm{C}$-NMR spectra (gated decoupling). Unequivocal assignments of signals was carried out by the combined application of standard NMR spectroscopic techniques such as ${ }^{1} \mathrm{H}$ coupled ${ }^{13} \mathrm{C}-\mathrm{NMR}$ spectra, APT, HMQC, gs-HSQC, gs-HMBC, COSY, TOSCY, NOESY and NOE difference spectroscopy. ${ }^{29}$ The elemental analyses were performed at the microanalytical laboratory (Faculty of Chemistry) and were in good agreement (+/- $0.4 \%)$ with the calculated values. For the microwave reaction system an Anton Paar Synthos 3000 was employed. Light petroleum refers to the fraction with boiling point $40-65^{\circ} \mathrm{C}$. Yields are not optimized.

Synthesis of 2-methyl-5-(2-pyridyl)-2,4-dihydro-3H-pyrazol-3-one (3a). ${ }^{30}$ To a solution of ethyl 3-oxo-3-(2-pyridyl)propionate (2) $(15.46 \mathrm{~g}, 80.00 \mathrm{mmol})$ in EtOH $(40 \mathrm{~mL})$ methylhydrazine $(4.3 \mathrm{~mL} ; 80.00 \mathrm{mmol})$ was added and the mixture was refluxed for $4 \mathrm{~h}$. Upon completion, the solvent was removed under reduced pressure and the residue was washed with light petroleum and dried in vacuo. The pyrazolone 3a was a colorless solid (13.39 g, 96\%), mp 135-136 ${ }^{\circ} \mathrm{C} .{ }^{1} \mathrm{H}$ NMR (400 MHz, $\left.\mathrm{CDCl}_{3}\right): \delta 3.43\left(\mathrm{~s}, 3 \mathrm{H}, \mathrm{CH}_{3}\right), 3.76\left(\mathrm{~s}, 2 \mathrm{H}, \mathrm{CH}_{2}\right), 7.29(\mathrm{~m}, 1 \mathrm{H}$, Pyr 5-H), 7.74 (m, 1H, Pyr 4-H), 7.93 (m, 1H, Pyr 3-H), 8.59 (m, 1H, Pyr 6-H) ppm. ${ }^{13} \mathrm{C}$ NMR $\left(100 \mathrm{MHz}, \mathrm{CDCl}_{3}\right): \delta 31.5\left({ }^{1} J_{\mathrm{NCH} 3} 140.1 \mathrm{~Hz}, \mathrm{CH}_{3}\right), 38.1\left({ }^{1} J_{\mathrm{C}-4,4-\mathrm{H}} 135.2\right.$ Hz,C-4), 120.0 (Pyr C-3), 124.3 (Pyr C-5), 136.5 (Pyr C-4), 149.5 (Pyr C-6), 149.9 (Pyr C-2), 155.2 (C-3), 172.6 (C-5) ppm. ${ }^{15} \mathrm{~N}$ NMR (40 MHz, $\left.\mathrm{CDCl}_{3}\right): \delta-201.8(\mathrm{~N}-1),-74.1$ (Pyr N-1), -45.8 (N-2) ppm. ${ }^{1} \mathrm{H}$ NMR (400 MHz, DMSO- $\left.d_{6}\right): \delta 3.71\left(\mathrm{~s}, 3 \mathrm{H}, \mathrm{CH}_{3}\right), 5.96(\mathrm{~s}, 1 \mathrm{H}, \mathrm{CH}), 7.35$ (m, 1H, Pyr 5-H), 7.87 (m, 1H, Pyr 4-H), 7.98 (m, 1H, Pyr 3-H), 8.58 (m, 1H, Pyr 6-H), 14.40 (s, $1 \mathrm{H}, \mathrm{OH}) \mathrm{ppm} .{ }^{13} \mathrm{C} \mathrm{NMR}\left(100 \mathrm{MHz}, \mathrm{DMSO}-d_{6}\right): \delta 33.7\left({ }^{1} J_{\mathrm{NCH} 3} 139.9 \mathrm{~Hz}, \mathrm{CH}_{3}\right), 85.7(\mathrm{C}-4)$, 122.5 (Pyr C-5), 123.3 (Pyr C-3), 138.7 (Pyr C-4), 144.2 (C-3), 146.4 (Pyr C-6), 152.8 (Pyr C-2), $153.3(\mathrm{C}-5)$ ppm. ${ }^{15} \mathrm{~N}$ NMR (40 MHz, DMSO- $\left.d_{6}\right): \delta-202.2(\mathrm{~N}-1),-102.2(\mathrm{Pyr} \mathrm{N}-1),-111.8(\mathrm{~N}-$ 2) ppm. HRMS: Calcd for $\left(\mathrm{C}_{9} \mathrm{H}_{9} \mathrm{~N}_{3} \mathrm{O}+\mathrm{H}\right)^{+}: 176.0818$. Found: 176.0820.

Synthesis of 2-(phenylmethyl)-5-(2-pyridyl)-2,4-dihydro-3H-pyrazol-3-one (3b). Under stirring at $0{ }^{\circ} \mathrm{C}$, benzylhydrazine $(1.22 \mathrm{~g}, 10.00 \mathrm{mmol})$ was added dropwise to ethyl 3-oxo-3-(2pyridyl)propionate (2) $(1.93 \mathrm{~g}, 10.00 \mathrm{mmol})$ and the mixture was stirred for $30 \mathrm{~min}$ at $0{ }^{\circ} \mathrm{C}$. The product $\mathbf{3 b}$ was filtered off, washed with cold $\mathrm{Et}_{2} \mathrm{O}$ and dried in vacuo, forming a colorless solid (2.01 g 79\%), mp 184-185 ${ }^{\circ} \mathrm{C} .{ }^{1} \mathrm{H}$ NMR (400 MHz, $\left.\mathrm{CDCl}_{3}\right): \delta 3.81\left(\mathrm{~s}, 2 \mathrm{H}, \mathrm{CH}_{2}\right), 4.96(\mathrm{~s}, 2 \mathrm{H}$, $\left.\mathrm{NCH}_{2}\right), 7.28$ (m, 1H, Pyr 5-H), 7.29 (m, 1H, Ph 4-H), 7.35 (m, 2H, Ph 3,5-H), 7.40 (m, 2H, Ph 2,6-H), 7.71 (m, 1H, Pyr 4-H), 7.95 (m, 1H, Pyr 3-H), 8.58 (m, 1H, Pyr 6-H) ppm. ${ }^{13} \mathrm{C}$ NMR (100 MHz, $\mathrm{CDCl}_{3}$ ): $\delta 38.2$ (C-4), $48.2\left(\mathrm{CH}_{2}\right), 120.1$ (Pyr C-3), 124.3 (Pyr C-5), 127.8 (Ph C-4), 128.2 (Ph C-2,6), 128.6 (Ph C-3,5), 136.4 (Pyr C-4), 136.5 (Ph C-1), 149.4 (Pyr C-6), 150.1 (Pyr C-2), 155.5 (C-3), 172.3 (C-5) ppm. ${ }^{15} \mathrm{~N}$ NMR (40 MHz, $\left.\mathrm{CDCl}_{3}\right): \delta-189.8(\mathrm{~N}-1),-73.8(\mathrm{Pyr} \mathrm{N}-$ 1), -47.6 (N-2) ppm. ${ }^{1} \mathrm{H}$ NMR (500 MHz, DMSO-d $): \delta 5.15\left(\mathrm{~s}, 2 \mathrm{H}, \mathrm{CH}_{2}\right), 5.98(\mathrm{~s}, 1 \mathrm{H}, 4-\mathrm{H})$, 7.21 (m, 2H, Ph 2,6-H), 7.23 (m, 1H, Pyr 5-H), 7.25 (m, 1H, Ph 4-H), 7.32 (m, 2H, Ph 3,5-H), 7.74 (m, 1H, Pyr 4-H), 7.84 (m, 1H, Pyr 3-H), 8.51 (m, 1H, Pyr 6-H), 11.30 (br s, 1H, OH) ppm.

${ }^{13} \mathrm{C}$ NMR (125 MHz, DMSO- $\left.d_{6}\right): \delta 49.7\left(\mathrm{CH}_{2}\right), 84.5$ (C-4), 118.6 (Pyr C-3), 122.3 (Pyr C-5), 
127.1 (Ph C-2,6), 127.2 (Ph C-4), 128.4 (Ph C-3,5), 136.4 (Pyr C-4), 137.7 (Ph C-1), 149.0 (Pyr C-6), 149.1 (C-3), 152.4 (Pyr C-2), 153.2 (C-5) ppm. ${ }^{15} \mathrm{~N}$ NMR (50 MHz, DMSO- $\left.d_{6}\right): \delta-189.7$ (N-1), -102.2 (N-2), -74.9 (Pyr N-1) ppm. MS: $m / z$ (\%): $251\left(\mathrm{M}^{+}, 40\right), 104$ (42), 91 (100), 78 (29). Anal. Calcd for $\mathrm{C}_{15} \mathrm{H}_{13} \mathrm{~N}_{3} \mathrm{O}$ (251.29): C, 71.70; H, 5.21; N, 16.72. Found: C, 71.35; H, 5.08; N, 16.40.

Synthesis of 2-(1,1-dimethylethyl)-5-(2-pyridyl)-2,4-dihydro-3H-pyrazol-3-one (3c). tertButylhydrazine hydrochloride $(7.85 \mathrm{~g}, 0.061 \mathrm{~mol})$ was dissolved in acetic acid $(20 \mathrm{~mL})$ and ethyl 3-oxo-3-(2-pyridyl)propionate (2) (9.8 g, $0.05 \mathrm{~mol}$ ) was added. The mixture was stirred at 110 ${ }^{\circ} \mathrm{C}$ for $3 \mathrm{~h}$. The reaction mixture was cooled to $\mathrm{rt}$ and neutralized with aqueous sodium hydrogen carbonate solution and then exhaustively extracted with ethyl acetate. The combined organic layers were washed with brine and dried over anhydrous sodium sulfate. The solvent was evaporated under reduced pressure and the residue was purified by column chromatography using ethyl acetate/light petroleum $(2: 1 \mathrm{v} / \mathrm{v})$ as the eluent. The pyrazolone $\mathbf{3 c}$ was isolated as a pale yellow solid (7.10 g, 65\%), mp 179-180 ${ }^{\circ} \mathrm{C} .{ }^{1} \mathrm{H}$ NMR (400 MHz, $\mathrm{CDCl}_{3}$ ): $\delta 1.57(\mathrm{~s}, 9 \mathrm{H}, 3 \times$ $\mathrm{CH}_{3}$ ), 3.75 (s, 2H, $\mathrm{CH}_{2}$ ), 7.25 (ddd, J 7.5, 4.9, $1.2 \mathrm{~Hz}, 1 \mathrm{H}, \mathrm{Pyr} 5-\mathrm{H}$ ), 7.71 (ddd, J 8.0, 7.5, $1.7 \mathrm{~Hz}$, 1H, Pyr 4-H), 7.96 (ddd, J 8.0, 1.2, 1.0 Hz, 1H, Pyr 3-H), 8.56 (ddd, J 4.9, 1.7, 1.0 Hz, 1H, Pyr

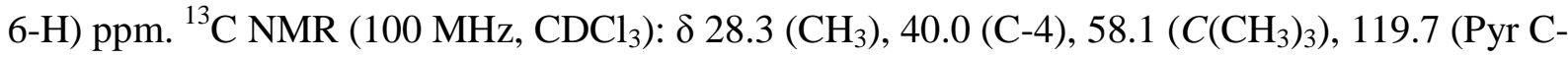
3), 123.9 (Pyr C-5), 136.3 (Pyr C-4), 149.3 (Pyr C-6), 150.6 (Pyr C-2), 153.2 (C-3), 172.8 (C-5) ppm. ${ }^{15} \mathrm{~N}$ NMR $\left(40 \mathrm{MHz}, \mathrm{CDCl}_{3}\right): \delta-176.5(\mathrm{~N}-1),-75.0(\mathrm{Pyr} \mathrm{N}-1),-44.3(\mathrm{~N}-2) \mathrm{ppm} . \mathrm{MS} \mathrm{m} / \mathrm{z}$ (\%): 217 (34) [M] $]^{+}, 202$ (48), 161 (100), 105 (25), 104 (95), 78 (30), 57 (40), 56 (28), 51 (24), 41 (40). HRMS: Calcd for $\left(\mathrm{C}_{12} \mathrm{H}_{15} \mathrm{~N}_{3} \mathrm{O}+\mathrm{H}\right)^{+}: 218.1288$. Found: 218.1291.

\section{Synthesis of 5-chloro-3-(2-pyridyl)-1H-pyrazole-4-carbaldehydes (4). General procedure.}

Under anhydrous conditions $\mathrm{POCl}_{3}(2.60 \mathrm{~mL}, 4.29 \mathrm{~g}, 28.00 \mathrm{mmol})$ was carefully added dropwise to dry DMF $(0.98 \mathrm{~mL}, 936 \mathrm{mg}, 12.80 \mathrm{mmol})$ under cooling. Then the appropriate 5-(2-pyridyl)2,4-dihydro-3H-pyrazol-3-one (3) $(4.00 \mathrm{mmol})$ was added and the mixture was heated to reflux for $2 \mathrm{~h}$. The reaction mixture was then cooled to room temperature and the dark coloured solution was poured into ice water with stirring. The reaction mixture was neutralized with $1 \mathrm{~N}$ $\mathrm{NaOH}$ until a precipitate formed and then extracted with ethyl acetate $(3 \times 10 \mathrm{~mL})$. The combined organic phases were dried $\left(\mathrm{Na}_{2} \mathrm{SO}_{4}\right)$, the solvent was removed under reduced pressure, and the residue was purified by column chromatography using ethyl acetate/light petroleum; 1:4 $\mathrm{v} / \mathrm{v}$.

5-Chloro-1-methyl-3-(2-pyridyl)-1H-pyrazole-4-carbaldehyde (4a). Yellow solid (628 mg, 70\%), mp 137-138 ${ }^{\circ} \mathrm{C}$ (lit. $\left.{ }^{31} \mathrm{mp} 135-136{ }^{\circ} \mathrm{C}\right) .{ }^{1} \mathrm{H} \mathrm{NMR}\left(400 \mathrm{MHz}, \mathrm{CDCl}_{3}\right): \delta 3.94\left(\mathrm{~s}, 3 \mathrm{H}, \mathrm{CH}_{3}\right)$, 7.30 (ddd, J 7.5, 4.9, 1.2 Hz, 1H, Pyr 5-H), 7.78 (ddd, J 8.0, 7.5, 1.8 Hz, 1H, Pyr 4-H), 7.99 (ddd, $J$ 8.0, 1.2, 1.0 Hz, 1H, Pyr 3-H), 8.65 (ddd, J 4.9, 1.8, 1.0 Hz, 1H, Pyr 6-H), 10.64 (s, 1H, CHO). ${ }^{13} \mathrm{C}$ NMR (100 MHz, $\left.\mathrm{CDCl}_{3}\right): \delta 36.4\left(\mathrm{CH}_{3}\right), 116.9(\mathrm{C}-4), 121.8$ (Pyr C-3), 123.6 (Pyr C-5), 131.8 (C-5), 136.7 (Pyr C-4), 149.4 (Pyr C-6), 151.1 (Pyr C-2), 151.7 (C-3), 186.9 (CHO). ${ }^{15} \mathrm{~N}$ NMR $\left(40 \mathrm{MHz}, \mathrm{CDCl}_{3}\right): \delta-179.5(\mathrm{~N}-1),-77.7(\mathrm{~N}-2),-71.7$ (Pyr N-1). HRMS: Calcd for $\left(\mathrm{C}_{10} \mathrm{H}_{8} \mathrm{ClN}_{3} \mathrm{O}+\mathrm{H}\right)^{+}:$222.0429. Found: 222.0430 . 
5-Chloro-1-(phenylmethyl)-3-(2-pyridyl)-1H-pyrazole-4-carbaldehyde (4b). Colorless solid (726 mg, 61\%), mp 122-123 ${ }^{\circ} \mathrm{C} .{ }^{1} \mathrm{H}$ NMR (400 MHz, $\mathrm{CDCl}_{3}$ ): $\delta 5.43$ (s, 2H, $\mathrm{CH}_{2}$ ), 7.29 (ddd, $J$ 7.6, 4.8, 1.2 Hz, 1H, Pyr 5-H), 7.30 (m, 2H, Ph 2,6-H), 7.32 (m, 1H, Ph 4-H), 7.33 (m, 2H, Ph 3,5-H), 7.77 (ddd, J 8.0, 7.6, 1.8 Hz, 1H, Pyr 4-H), 8.03 (ddd, J 8.0, 1.2, 0.9 Hz, 1H, Pyr 3-H), 8.64 (ddd, $J$ 4.8, 1.8, $0.9 \mathrm{~Hz}, 1 \mathrm{H}$, Pyr 6-H), 10.71 (s, 1H, CHO) ppm. ${ }^{13} \mathrm{C}$ NMR (100 MHz, $\left.\mathrm{CDCl}_{3}\right): \delta 53.1\left(\mathrm{CH}_{2}\right), 117.2\left({ }^{2} J_{\mathrm{C}-4, \mathrm{CHO}}=26.0 \mathrm{~Hz}, \mathrm{C}-4\right), 121.9(\mathrm{Pyr} \mathrm{C}-3), 123.5(\mathrm{Pyr} \mathrm{C}-5), 127.7$ (Ph C-2,6), 128.4 (Ph C-4), 128.9 (Ph C-3,5), $131.3\left({ }^{3} J_{\mathrm{C}-5, \mathrm{CHO}}=5.9 \mathrm{~Hz},{ }^{3} J_{\mathrm{C}-5, \mathrm{CH} 2}=3.2 \mathrm{~Hz}, \mathrm{C}-5\right)$, 134.5 (Ph C-1), 136.7 (Pyr C-4), 149.3 (Pyr C-6), 151.2 (Pyr C-2), 152.1 (C-3), 187.2 ( ${ }^{1} J_{\mathrm{CHO}}=$ $186.9 \mathrm{~Hz}, C \mathrm{HO})$ ppm. ${ }^{15} \mathrm{~N}$ NMR $\left(40 \mathrm{MHz}, \mathrm{CDCl}_{3}\right): \delta-169.0(\mathrm{~N}-1),-77.7(\mathrm{~N}-2),-71.2(\mathrm{Pyr} \mathrm{N}-$ 1) ppm. MS m/z (\%): $298\left(\mathrm{M}^{+}, 8\right), 234$ (34), 91 (100), 65 (31). Anal. Calcd for $\mathrm{C}_{16} \mathrm{H}_{12} \mathrm{ClN}_{3} \mathrm{O}$ (297.74): C, 64.54; H, 4.06; N, 14.11. Found: C, 64.27; H, 3.85; N, $13.98 \%$.

5-Chloro-1-(1,1-dimethylethyl)-3-(2-pyridyl)-1H-pyrazole-4-carbaldehyde (4c). Pale yellow solid (105 mg, 10\%), mp 91-92 ${ }^{\circ} \mathrm{C} .{ }^{1} \mathrm{H}$ NMR (400 MHz, $\left.\mathrm{CDCl}_{3}\right): \delta 1.79\left(\mathrm{~s}, 9 \mathrm{H}, 3 \times \mathrm{CH}_{3}\right), 7.27$ (ddd, $J$ 7.5, 4.9, 1.2 Hz, 1H, Pyr 5-H), 7.76 (ddd, J 8.0, 7.5, 1.8 Hz, 1H, Pyr 4-H), 7.99 (ddd, $J$ 8.0, 1.2, $1.0 \mathrm{~Hz}, 1 \mathrm{H}$, Pyr 3-H), 8.63 (ddd, J 4.9, 1.8, 1.0 Hz, 1H, Pyr 6-H), 10.71 (s, 1H, CHO). ${ }^{13} \mathrm{C}$ NMR $\left(100 \mathrm{MHz}, \mathrm{CDCl}_{3}\right): \delta 29.1\left(\mathrm{CH}_{3}\right), 63.2\left(\mathrm{C}\left(\mathrm{CH}_{3}\right)_{3}\right), 118.3(\mathrm{C}-4), 121.8(\mathrm{Pyr} \mathrm{C}-3), 123.2$ (Pyr C-5), 129.7 (C-5), 136.5 (Pyr C-4), 149.2 (Pyr C-6), 149.6 (C-3), 151.7 (Pyr C-2), 187.7 (CHO). MS m/z (\%): 263 (1) [M] ${ }^{+}, 206$ (32), 181 (35), 179 (100), 78 (25). HRMS: Calcd for $\left(\mathrm{C}_{13} \mathrm{H}_{14} \mathrm{ClN}_{3} \mathrm{O}+\mathrm{H}\right)^{+}: 264.0898$. Found: 264.0899 .

Synthesis of 3-(2-pyridyl)-1H-pyrazolo[4,3-c]pyridines (6). General procedure. A mixture of 3-(2-pyridyl)-1 $H$-pyrazole-4-carbaldehyde (4) (1.00 mmol), $\mathrm{PdCl}_{2}\left(\mathrm{PPh}_{3}\right)_{2}$ (40 mg, $0.06 \mathrm{mmol}$ ), DMF (12 mL), phenylacetylene (151 mg, $1.50 \mathrm{mmol})$ and tert-butylamine (0793 g, $10.00 \mathrm{mmol})$ was irradiated in a microwave oven at $800 \mathrm{~W}$ for $1 \mathrm{~h}$ at $150{ }^{\circ} \mathrm{C}$ in a sealed vessel. The reaction mixture was cooled to $\mathrm{rt}$ and the solvents were removed under reduced pressure. The residue was dissolved in ethyl acetate $(25 \mathrm{~mL})$ and $\mathrm{H}_{2} \mathrm{O}(28 \mathrm{~mL})$ was added. The organic phase was separated and the aqueous phase was extracted with ethyl acetate $(3 \times 25 \mathrm{~mL})$. The organic layers were combined, washed with brine and dried over anhydrous sodium sulfate. The solvent was evaporated under reduced pressure and the residue was purified by column chromatography.

1-Methyl-6-phenyl-3-(2-pyridyl)-1H-pyrazolo[4,3-c]pyridine (6a). Compound 6a was purified by column chromatography using ethyl acetate/light petroleum, 1:3 v/v. Yellow solid (78 mg, 26\%), mp 145-146 ${ }^{\circ} \mathrm{C} .{ }^{1} \mathrm{H}$ NMR (500 MHz, $\left.\mathrm{CDCl}_{3}\right): \delta 4.15\left(\mathrm{~s}, 3 \mathrm{H}, \mathrm{CH}_{3}\right), 7.29(\mathrm{~m}, 1 \mathrm{H}$, Pyr 5-H), 7.43 (m, 1H, Ph 4-H), 7.51 (m, 2H, Ph 3,5-H), 7.64 (d, J 1.2 Hz, 1H, 7-H), 7.79 (m, 1H, Pyr 4-H), 8.09 (m, 2H, Ph 2,6-H), 8.15 (m, 1H, Pyr 3-H), 8.77 (m, 1H, Pyr 6-H), 9.96 (d, $J$ $1.2 \mathrm{~Hz}, 1 \mathrm{H}, 4-\mathrm{H}) \mathrm{ppm} .{ }^{13} \mathrm{C} \mathrm{NMR}\left(125 \mathrm{MHz}, \mathrm{CDCl}_{3}\right): \delta 35.6\left(\mathrm{CH}_{3}\right), 99.8\left({ }^{1} J_{\mathrm{C} 7,7 \mathrm{H}}=163.5 \mathrm{~Hz}\right.$, $\left.{ }^{4} J_{\mathrm{C} 7,4 \mathrm{H}}=1.7 \mathrm{~Hz}, \mathrm{C}-7\right), 118.8$ (C-3a), 120.7 (Pyr C-3), 122.9 (Pyr C-5), 127.3 (Ph C-2,6), 128.69 (Ph C-4), 128.73 (Ph C-3,5), 136.4 (Pyr C-4), 139.9 (Ph C-1), 144.3 (C-3), 145.5 (C-7a), 147.8 $\left({ }^{1} J_{\mathrm{C} 4,4 \mathrm{H}}=186.6 \mathrm{~Hz},{ }^{4} J_{\mathrm{C} 4,7 \mathrm{H}}=0.6 \mathrm{~Hz}, \mathrm{C}-4\right), 149.7(\mathrm{Pyr} \mathrm{C}-6), 152.2(\mathrm{Pyr} \mathrm{C}-2), 152.9(\mathrm{C}-6) \mathrm{ppm}$. ${ }^{15} \mathrm{~N}$ NMR $\left(50 \mathrm{MHz}, \mathrm{CDCl}_{3}\right): \delta-206.8(\mathrm{~N}-1),-91.3(\mathrm{~N}-5),-73.3(\mathrm{Pyr} \mathrm{N}-1),-62.2(\mathrm{~N}-2) . \mathrm{MS} \mathrm{m} / \mathrm{z}$ (\%): 287 (21), 286 ( $\left.\mathrm{M}^{+}, 100\right), 285$ (65), 209 (49), 105 (28), 91 (31), 79 (26), 78 (40), 71 (20), 57 (30), 51 (20), 43 (43) ppm. HRMS: Calcd for $\left(\mathrm{C}_{18} \mathrm{H}_{14} \mathrm{~N}_{4}+\mathrm{H}\right)^{+}: 287.1291$. Found: 287.1292. 
1-Methyl-3,6-di-(2-pyridyl)-1H-pyrazolo[4,3-c]pyridine (6b). Compound $6 \mathrm{~b}$ was purified by column chromatography using ethyl acetate $\rightarrow$ dichloromethane / $\mathrm{MeOH}, 9: 1 \mathrm{v} / \mathrm{v}$. Colorless solid (232 mg, 81\%), mp 157-158 ${ }^{\circ} \mathrm{C} .{ }^{1} \mathrm{H}$ NMR (400 MHz, $\left.\mathrm{CDCl}_{3}\right): \delta 4.17\left(\mathrm{~s}, 3 \mathrm{H}, \mathrm{CH}_{3}\right), 7.26(\mathrm{~m}$, 1H, C-3-Pyr 5-H), 7.30 (m, 1H, C-6-Pyr 5-H), 7.77 (m, 1H, C-3-Pyr 4-H), 7.83 (m, 1H, C-6-Pyr 4-H), 8.14 (m, 1H, C-3-Pyr 3-H), 8.43 (s, 1H, 7-H), 8.56 (m, 1H, C-6-Pyr 3-H), 8.68 (m, 1H, C6-Pyr 6-H), 8.75 (m, 1H, C-3-Pyr 6-H), 9.93 (s, 1H, 4-H) ppm. $\left.{ }^{13} \mathrm{C} \mathrm{NMR} \mathrm{(100} \mathrm{MHz,} \mathrm{CDCl}_{3}\right): \delta$ $35.8\left(\mathrm{CH}_{3}\right), 106.6$ (C-7), 119.6 (C-3a), 120.6 (C-3-Pyr C-3), 121.8 (C-6-Pyr C-3), 122.9 (C-3-Pyr C-5), 123.5 (C-6-Pyr C-5), 136.4 (C-3-Pyr C-4), 137.0 (C-6-Pyr C-4), 144.3 (C-3), 145.5 (C-7a), 147.4 (C-4), 149.0 (C-6-Pyr C-6), 149.6 (C-3-Pyr C-6), 151.2 (C-6), 152.2 (C-3-Pyr C-2), 156.3 (C-6-Pyr C-2) ppm. ${ }^{15} \mathrm{~N}$ NMR (40 MHz, $\left.\mathrm{CDCl}_{3}\right): \delta-205.1(\mathrm{~N}-1),-93.7(\mathrm{~N}-5),-79.3(\mathrm{C}-6-\mathrm{Pyr}$ $\mathrm{N}-1),-73.6$ (C-3-Pyr N-1), -60.9 (N-2) ppm. MS m/z (\%): $287\left(\mathrm{M}^{+}, 33\right), 278$ (38), 277 (100), 204 (31), 77 (23), 57 (20), 51 (25). Anal. Calcd for $\mathrm{C}_{17} \mathrm{H}_{13} \mathrm{~N}_{5}$ (287.33)•0.3 $\mathrm{H}_{2} \mathrm{O}: \mathrm{C}, 69.75$; $\mathrm{H}$, $4.68 ; \mathrm{N}, 23.92$. Found: C, 69.78; H, 4.30; N, $23.84 \%$.

1-Methyl-3-(2-pyridyl)-6-(3-pyridyl)-1H-pyrazolo[4,3-c]pyridine (6c). Compound 6c was purified by column chromatography using ethyl acetate. Pale yellow solid (192 mg, 67\%), mp 170-172 ${ }^{\circ} \mathrm{C} .{ }^{1} \mathrm{H}$ NMR $\left(400 \mathrm{MHz}, \mathrm{CDCl}_{3}\right.$ ): $\delta 4.15$ (s, 3H, $\mathrm{CH}_{3}$ ), 7.28 (ddd, J 7.5, 4.8, $1.1 \mathrm{~Hz}, 1 \mathrm{H}$, 2-Pyr 5-H), 7.41 (ddd, J 8.0, 4.8, $0.8 \mathrm{~Hz}, 1 \mathrm{H}, 3-\mathrm{Pyr} 5-\mathrm{H}), 7.63$ (d, J 1.1 Hz, 1H, 7-H), 7.77 (ddd, $J$ 7.6, 7.6, 1.7 Hz, 1H, 2-Pyr 4-H), 8.13 (ddd, J 8.0, 1.1, $1.1 \mathrm{~Hz}, 1 \mathrm{H}, 2-\mathrm{Pyr} 3-\mathrm{H}$ ), 8.41 (ddd, J 8.0, 2.2, 1.7 Hz, 1H, 3-Pyr 4-H), 8.64 (dd, J 4.8, 1.5 Hz, 1H, 3-Pyr 6-H), 8.75 (ddd, J 4.8, 1.7, 0.9 Hz, 1H, 2-Pyr 6-H), 9.26 (d, J 2.0 Hz, 1H, 3-Pyr 2-H), 9.96 (d, J 1.1 Hz, 1H, 4-H) ppm. ${ }^{13} \mathrm{C} \mathrm{NMR}$ $\left(100 \mathrm{MHz}, \mathrm{CDCl}_{3}\right): \delta 35.7\left(\mathrm{CH}_{3}\right), 100.1$ (C-7), 119.0 (C-3a), 120.6 (2-Pyr C-3), 123.0 (2-Pyr C5), 123.5 (3-Pyr C-5), 134.8 (3-Pyr C-4), 135.4 (3-Pyr C-3), 136.5 (2-Pyr C-4), 144.4 (C-3), 145.1 (C-7a), 148.29 (C-4), 148.33 (3-Pyr C-2), 149.6 (3-Pyr C-6), 149.7 (2-Pyr C-6), 149.9 (C6), 152.0 (2-Pyr C-2) ppm. ${ }^{15} \mathrm{~N}$ NMR (40 MHz, $\left.\mathrm{CDCl}_{3}\right): \delta-206.1$ (N-1), -91.7 (N-5), -73.4 (2Pyr N-1), -70.7 (3-Pyr N-1), -61.1 (N-2) ppm. MS m/z (\%): 288 (20), 287 (M+100), 286 (62), 209 (35), 78 (27). Anal. Calcd for $\mathrm{C}_{17} \mathrm{H}_{13} \mathrm{~N}_{5}$ (287.33)·0.15 $\mathrm{H}_{2} \mathrm{O}: \mathrm{C}, 70.40 ; \mathrm{H}, 4.62 ; \mathrm{N}, 24.15$. Found: C, 70.41; H, 4.34; N, $23.83 \%$.

1-(Phenylmethyl)-3-(2-pyridyl)-6-(3-pyridyl)-1H-pyrazolo[4,3-c]pyridine (6d). Compound 6d was purified by column chromatography using ethyl acetate. Pale yellow solid (211 mg, 58\%), mp 179-180 ${ }^{\circ} \mathrm{C} .{ }^{1} \mathrm{H}$ NMR (500 MHz, $\left.\mathrm{CDCl}_{3}\right): \delta 5.68\left(\mathrm{~s}, 2 \mathrm{H}, \mathrm{CH}_{2}\right), 7.27(\mathrm{~m}, 1 \mathrm{H}, \mathrm{Ph} 2-\mathrm{H})$, 7.29 (m, 2H, Ph 4-H, 2-Pyr 5-H), 7.33 (m, 2H, Ph 3,5-H), 7.38 (m, 1H, 3-Pyr 5-H), 7.55 (d, J 1.2 $\mathrm{Hz}, 1 \mathrm{H}, 7-\mathrm{H}$ ), 7.78 (ddd, $J$ 8.0, 7.5, $1.8 \mathrm{~Hz}, 1 \mathrm{H}, 2-\mathrm{Pyr} 4-\mathrm{H}), 8.20$ (ddd, J 8.0, 1.0, $1.0 \mathrm{~Hz}, 1 \mathrm{H}, 2$ Pyr 3-H), 8.35 (m, 1H, 3-Pyr 4-H), 8.62 (m, 1H, 3-Pyr 6-H), 8.77 (ddd, J 4.8, 1.7, 0.9 Hz, 1H, 2Pyr 6-H), 9.16 (dd, $J 2.3,0.8 \mathrm{~Hz}, 1 \mathrm{H}, 3-\mathrm{Pyr} 2-\mathrm{H}), 10.02$ (d, $J 1.2 \mathrm{~Hz}, 1 \mathrm{H}, 4-\mathrm{H})$ ppm. ${ }^{13} \mathrm{C} \mathrm{NMR}$ $\left(125 \mathrm{MHz}, \mathrm{CDCl}_{3}\right): \delta 53.3\left({ }^{1} J_{\mathrm{CH} 2} 139.7 \mathrm{~Hz}, \mathrm{CH}_{2}\right), 100.5\left({ }^{1} J_{\mathrm{C}-7,7-\mathrm{H}} 164.1 \mathrm{~Hz},{ }^{4} J_{\mathrm{C}-7,4-\mathrm{H}} 1.7 \mathrm{~Hz}, \mathrm{C}-7\right)$, 119.5 (C-3a), 120.9 (2-Pyr C-3), 123.1 (2-Pyr C-5), 123.5 (3-Pyr C-5), 127.2 (Ph C-2,6), 128.2 (Ph C-4), 128.9 (Ph C-3,5), 134.8 (3-Pyr C-4), 135.3 (3-Pyr C-3), 135.7 (Ph C-1), 136.4 (2-Pyr C-4), 144.8 (C-3), 144.9 (C-7a), 148.4 (3-Pyr C-2), $148.5\left({ }^{1} J_{\mathrm{C}-4,4-\mathrm{H}} 187.4\right.$ Hz, C-4), 149.58 (3-Pyr C-6), 149.64 (2-Pyr C-6), 150.1 (C-6), 152.1 (2-Pyr C-2) ppm. ${ }^{15} \mathrm{~N}$ NMR (50 MHz, $\mathrm{CDCl}_{3}$ ): $\delta$ $-195.4(\mathrm{~N}-1),-90.9$ (N-5), -73.2 (2-Pyr N-1), -70.3 (3-Pyr N-1), -61.0 (N-2) ppm. MS m/z 
(\%): $363\left(\mathrm{M}^{+}, 60\right), 362$ (33), 287 (39), 286 (92), 285 (46), 209 (34), 95 (21), 91 (100), 78 (24), 69 (68), 57 (29), 43 (22), 41 (24). Anal. Calcd for $\mathrm{C}_{23} \mathrm{H}_{17} \mathrm{~N}_{5}(363.43) \bullet 0.1 \mathrm{H}_{2} \mathrm{O}: \mathrm{C}, 75.64 ; \mathrm{H}, 4.75$; N, 19.18. Found: C, 75.53; H, 4.48; N, $18.87 \%$.

1-(1,1-Dimethylethyl)-3-(2-pyridyl)-6-(3-pyridyl)-1H-pyrazolo[4,3-c]pyridine (6e). Compound 6e was synthesized in analogy to compound 6a from $4 \mathbf{c}(205 \mathrm{mg}, 0.75 \mathrm{mmol})$ except that 3ethynylpyridine (116 mg, $1.125 \mathrm{mmol}$ ) was used. Purification was achieved by column chromatography using ethyl acetate/light petroleum, 1:5, v/v. Pale yellow solid (225 mg, 91\%), mp 172-174 ${ }^{\circ} \mathrm{C} .{ }^{1} \mathrm{H}$ NMR $\left(400 \mathrm{MHz}, \mathrm{CDCl}_{3}\right): \delta 1.87$ (s, 9H, $\left.3 \times \mathrm{CH}_{3}\right), 7.27(\mathrm{~m}, 1 \mathrm{H}, 2-\mathrm{Pyr}$ 5-H), 7.43 (m, 1H, 3-Pyr 5-H), 7.78 (m, 1H, 2-Pyr 4-H), 7.93 (d, J 1.1 Hz, 1H, 7-H), 8.20 (m, 1H, 2Pyr 3-H), 8.41 (m, 1H, 3-Pyr 4-H), 8.65 (m, 1H, 3-Pyr 6-H), 8.75 (m, 1H, 2-Pyr 6-H), 9.24 (m, 1H, 3-Pyr 2-H), 10.07 (d, J 1.1 Hz, 1H, 4-H). $\left.{ }^{13} \mathrm{C} \mathrm{NMR} \mathrm{(100} \mathrm{MHz,} \mathrm{CDCl}_{3}\right): \delta 29.8\left(\mathrm{CH}_{3}\right), 60.9$ $\left(C\left(\mathrm{CH}_{3}\right)_{3}\right), 103.3$ (C-7), 120.4 (C-3a), 120.8 (2-Pyr C-3), 122.7 (2-Pyr C-5), 123.6 (3-Pyr C-5), 135.0 (3-Pyr C-4), 135.9 (3-Pyr C-3), 136.3 (2-Pyr C-4), 142.6 (C-3), 143.4 (C-7a), 148.4 (3-Pyr C-2), 148.8 (C-4), 149.1 (C-6), 149.4 (3-Pyr C-6), 149.5 (2-Pyr C-6), 152.6 (2-Pyr C-2). ${ }^{15} \mathrm{~N}$ NMR (40 MHz, $\left.\mathrm{CDCl}_{3}\right)$ : $\delta-175.1(\mathrm{~N}-1),-92.7(\mathrm{~N}-5),-73.8$ (2-Pyr N-1), -70.5 (3-Pyr N-1), -58.0 (N-2). MS m/z (\%): 329 (45) [M] $]^{+}, 274$ (20), 273 (100), 272 (47), 78 (41), 69 (25), 57 (52), 41 (30). HRMS: Calcd for $\left(\mathrm{C}_{20} \mathrm{H}_{19} \mathrm{~N}_{5}+\mathrm{H}\right)^{+}: 330.1713$. Found: 330.1716.

1-(1,1-Dimethylethyl)-3-(2-pyridyl)-6-(3-thienyl)-1H-pyrazolo[4,3-c]pyridine (6f). Compound 6f was purified by column chromatography using ethyl acetate/light petroleum, 1:5 v/v. Pale yellow solid (280 mg, 84\%), mp 193-194 ${ }^{\circ} \mathrm{C} .{ }^{1} \mathrm{H}$ NMR (400 MHz, $\left.\mathrm{CDCl}_{3}\right): \delta 1.86$ (s, 9H, $3 \times$ $\mathrm{CH}_{3}$ ), 7.26 (ddd, J 7.5, 4.9, 1.2 Hz, 1H, Pyr 5-H), 7.43 (dd, J 5.1, 3.1 Hz, 1H, Th 5-H), 7.71 (dd, $J$ 5.1, 1.3 Hz, 1H, Th 4-H), 7.77 (ddd, J 8.0, 7.5, $1.8 \mathrm{~Hz}, 1 \mathrm{H}, \mathrm{Pyr} 4-\mathrm{H}), 7.81$ (d, J 1.2 Hz, 1H, 7H), 8.00 (dd, J 3.1, $1.3 \mathrm{~Hz}, 1 \mathrm{H}$, Th 2-H), 8.19 (ddd, J 8.0, 1.2, $1.0 \mathrm{~Hz}, 1 \mathrm{H}$, Pyr 3-H), 8.74 (ddd, $J$ 4.8, 1.8, $1.0 \mathrm{~Hz}, 1 \mathrm{H}$, Pyr 6-H), 9.99 (d, J 1.2 Hz, 1H, 4-H). ${ }^{13} \mathrm{C} \mathrm{NMR}\left(100 \mathrm{MHz}, \mathrm{CDCl}_{3}\right): \delta 29.7$

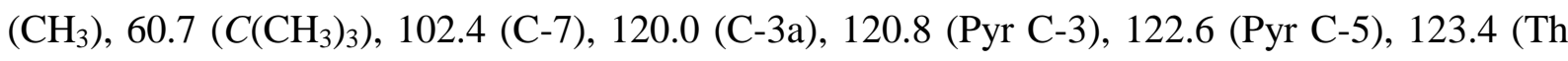
C-2), 126.2 (Th C-5), 126.3 (Th C-4), 136.3 (Pyr C-4), 142.6 (C-3), 142.8 (Th C-3), 143.5 (C7a), 147.9 (C-6), 148.4 (C-4), 149.5 (Pyr C-6), 152.8 (Pyr C-2). ${ }^{15} \mathrm{~N}$ NMR (40 MHz, CDCl 3 ): $\delta$ $-175.8(\mathrm{~N}-1),-93.7(\mathrm{~N}-5),-73.7$ (Pyr N-1), N-2 not found. MS m/z (\%): 334 (46) [M] $]^{+}, 279$ (21), 278 (100), 277 (56). HRMS: Calcd for $\left(\mathrm{C}_{19} \mathrm{H}_{18} \mathrm{~N}_{4} \mathrm{~S}+\mathrm{H}\right)^{+}:$335.1325. Found: 335.1328.

Synthesis of 3-(2-pyridyl)-6-(3-pyridyl)-1H-pyrazolo[4,3-c]pyridine (7a). Compound 6e (130 $\mathrm{mg}, 0.40 \mathrm{mmol})$ was dissolved in conc. sulfuric acid $(10 \mathrm{~mL})$ and the solution was stirred for $3 \mathrm{~h}$. The reaction mixture was cooled and neutralized with $1 \mathrm{~N} \mathrm{NaOH}$ and then extracted with ethyl acetate $(3 \times 50 \mathrm{~mL})$. The organic layers were combined, washed with brine and dried over anhydrous sodium sulfate. The solvent was evaporated under reduced pressure and the residue was purified by column chromatography using dichloromethane/MeOH, 9:1, v/v to give 7a. Yield: $60 \mathrm{mg}(55 \%)$; pale yellow solid; mp 324-326 ${ }^{\circ} \mathrm{C} .{ }^{1} \mathrm{H}$ NMR $\left(400 \mathrm{MHz}, \mathrm{CDCl}_{3}\right): \delta 7.45$ (m, 1H, 2-Pyr 5-H), 7.53 (m, 1H, 3-Pyr 5-H), 7.95 (m, 1H, 2-Pyr 4-H), 8.17 (d, J 1.1 Hz, 1H, 7-H), 8.21 (m, 1H, 2-Pyr 3-H), 8.54 (m, 1H, 3-Pyr 4-H), 8.63 (m, 1H, 3-Pyr 6-H), 8.78 (m, 1H, 2-Pyr 6-H), 9.37 (m, 1H, 3-Pyr 2-H), 9.88 (s, 1H, 4-H), 13.89 (s, 1H, NH) ppm. ${ }^{13} \mathrm{C}$ NMR (100 MHz, $\mathrm{CDCl}_{3}$ ): $\delta 101.8$ (C-7), 117.8 (C-3a), 120.3 (2-Pyr C-3), 123.4 (2-Pyr C-5), 123.7 (3-Pyr C-5), 
134.3 (3-Pyr C-4), 134.6 (3-Pyr C-3), 137.2 (2-Pyr C-4), 144.1 (C-3), 145.3 (C-7a), 147.1 (C-4), 148.1 (3-Pyr C-2), 148.7 (C-6), 149.5 (3-Pyr C-6), 149.7 (2-Pyr C-6), 152.0 (2-Pyr C-2) ppm. ${ }^{15} \mathrm{~N}$ NMR $\left(40 \mathrm{MHz}, \mathrm{CDCl}_{3}\right): \delta-194.6(\mathrm{~N}-1),-88.9(\mathrm{~N}-5),-72.6(2-\mathrm{Pyr} \mathrm{N}-1),-65.7(\mathrm{~N}-2),-65.3$ (3-Pyr N-1) ppm. MS m/z (\%): 273 (100) [M] ${ }^{+}, 272$ (56), 78 (37). HRMS: Calcd for $\left(\mathrm{C}_{16} \mathrm{H}_{11} \mathrm{~N}_{5}+\mathrm{H}\right)^{+}:$274.1087. Found: 274.1089 .

\section{Biological tests}

Kinase inhibition assays. CDK2/Cyclin $\mathrm{E}$ kinase was produced in $\mathrm{Sf} 9$ insect cells via baculoviral infection and purified on a NiNTA column (Qiagen). CDK5/p35, CDK7Cyclin H/MAT1 and CDK9/Cyclin T1 were purchased from ProQinase GmbH. The kinase reactions were assayed with $1 \mathrm{mg} / \mathrm{mL}$ histone $\mathrm{H} 1$ (for CDK2 and CDK5) or (YSPTSPS) 2 KK peptide (for CDK7 and CDK9) in the presence of 15/0.15/1.5/1.5 $\mu \mathrm{M}$ ATP (for CDK2/CDK5/CDK7CDK9), $0.05 \mu \mathrm{Ci}\left[\gamma^{33} \mathrm{P}\right] \mathrm{ATP}$ and of the test compound in a final volume of $10 \mu \mathrm{L}$, all in a reaction buffer (60 mM HEPES- $\mathrm{NaOH}, \mathrm{pH} 7.5,3 \mathrm{mM} \mathrm{MgCl}, 3 \mathrm{mM} \mathrm{MnCl}_{2}, 3 \mu \mathrm{M}$ Na-orthovanadate, $1.2 \mathrm{mM}$ DTT, $2.5 \mu \mathrm{g} / 50 \mu \mathrm{PEG}_{20.000}$ ). The reactions were stopped by adding $5 \mu \mathrm{L}$ of $3 \%$ aq. $\mathrm{H}_{3} \mathrm{PO}_{4}$. Aliquots were spotted onto P-81 phosphocellulose (Whatman), washed $3 \times$ with $0.5 \%$ aq. $\mathrm{H}_{3} \mathrm{PO}_{4}$ and finally air-dried. Kinase inhibition was quantified using a FLA-7000 digital image analyzer (Fujifilm). The concentration of the test compounds required to decrease the CDK activity by 50 $\%$ was determined from dose-response curves and designated as $\mathrm{IC}_{50}{ }^{28}$

Cell maintenance and cytotoxicity assays. The cytotoxicity of the studied compounds was determined using cell lines of different histological origin as described earlier. ${ }^{28}$ Briefly, the cells were assayed with compounds using three-fold dilutions in triplicate. Treatment lasted for $72 \mathrm{~h}$, followed by addition of Calcein AM solution, and measurement of the fluorescence of live cells at $485 \mathrm{~nm} / 538 \mathrm{~nm}$ (ex/em) with a Fluoroskan Ascent microplate reader (Labsystems). $\mathrm{IC}_{50}$ (the drug concentration that reduced the number of viable cells to $50 \%$ ) values were determined from the dose-response curves.

\section{Acknowledgements}

The authors gratefully acknowledge financial support by the program AKTION Österreich Tschechien (project 62p9).

\section{References}

1. Zhang, J.; Yang, P. L.; Gray, N. S. Nat. Rev. Cancer 2009, 9, 28. http://dx.doi.org/10.1038/nrc2559

2. Malumbres, M.; Barbacid, M. Nat. Rev. Cancer 2009, 9, 153. http://dx.doi.org/10.1038/nrc2602

3. Leitch, A. E.; Haslett, C.; Rossi, A. G. Br. J. Pharmacol. 2009, 158, 1004. 
http://dx.doi.org/10.1111/j.1476-5381.2009.00402.x

4. Krystof, V.; Uldrijan, S. Curr. Drug Targets 2010, 11, 291.

http://dx.doi.org/10.2174/138945010790711950

5. Havlicek, L.; Hanus, J.; Vesely, J.; Leclerc, S.; Meijer, L.; Shaw, G.; Strnad, M. J. Med. Chem. 1997, 40, 408.

http://dx.doi.org/10.1021/jm960666x

6. Benson, C.; White, J.; De Bono, J.; O’Donnell, A.; Raynaud, F.; Cruickshank, C.; McGrath, H.; Walton, M.; Workman, P.; Kaye, S.; Cassidy, J.; Gianella-Borradori, A.; Judson, I.; Twelves, C. Br. J. Cancer 2007, 96, 29. http://dx.doi.org/10.1038/sj.bjc.6603509

7. Le Tourneau, C.; Faivre, S.; Laurence, V.; Delbaldo, C.; Vera, K.; Girre, V.; Chiao, J.; Armour, S.; Frame, S.; Green, S. R.; Gianella-Borradori, A.; Diéras, V.; Raymond, E. Eur. J. Cancer 2010, 46, 3243. http://dx.doi.org/10.1016/j.ejca.2010.08.001

8. Jorda, R.; Paruch, K.; Krystof, V. Curr. Pharm. Des. 2012, 18, 2974. http://dx.doi.org/10.2174/138161212800672804

9. Jorda, R.; Havlicek, L.; McNae, I. W.; Walkinshaw, M. D.; Voller, J.; Sturc, A.; Navratilova, J.; Kuzma, M.; Mistrik, M.; Bartek, J.; Strnad, M.; Krystof, V. J. Med. Chem. 2011, 54, 2980 .

http://dx.doi.org/10.1021/jm200064p

10. Vilkauskaitè, G.; Šačkus, A.; Holzer, W. Eur. J. Org. Chem. 2011, 5123.

http://dx.doi.org/10.1002/ejoc.201100626

11. Eller, G. A.; Holzer, W. Heterocycles 2004, 63, 2537.

http://dx.doi.org/10.3987/COM-04-10190

12. Becker, W.; Eller, G. A.; Holzer, W. Synthesis 2005, 2583.

http://dx.doi.org/10.1055/s-2005-872078

13. Eller, G. A.; Wimmer, V.; Haring, A. W.; Holzer, W. Synthesis 2006, 4219. http://dx.doi.org/10.1007/s10593-007-0165-z

14. Jones, G.; Stanforth, S. P. in Organic Reactions; Paquette, L. A. Eds.; Wiley: New York, 1997; Vol. 49, pp 1-330.

http://dx.doi.org/10.1002/0471264180.or049.01

15. Becher, J.; Pluta, K.; Krake, N. J.; Brøndum, K.; Christensen, N. J.; Vinader, M. V. Synthesis 1989, 530.

http://dx.doi.org/10.1055/s-1989-27307

16. Holzer, W.; Vilkauskaite, G.; Arbačiauskienė, E.; Šačkus, A. Beilstein J. Org. Chem. 2012, 8, 2223.

http://dx.doi.org/10.3762/bjoc.8.251

17. Chinchilla, R.; Najera, C. Chem. Rev. 2007, 107, 874.

http://dx.doi.org/10.1021/cr050992x

18. Müller, T. J. J. Beilstein J. Org. Chem. 2011, 7, 960. 
http://dx.doi.org/10.3762/bjoc.7.107

19. Multicomponent Reactions; Zhu, J.; Bienayme, H. Eds.; Wiley-VCH: Weinheim, 2005.

20. Butler, D. E.; deWald, H. A. J. Org. Chem. 1975, 40, 1353.

http://dx.doi.org/10.1021/jo00897a041

21. Barawka, D. A.; Merut, A.; Bandyopadhyay, A.; Banerjee, A.; Deshpande, A. M.; Athare, C.; Koduru, C.; Khose, G.; Gundu, J.; Mahajan, K.; Patil, P.; Kandalkar, S. R.; Niranjan, S. ; Bhosale, S.; De, S.; Mukhopadhyay, S.; Chaudhary, S.; Koul, S.; Singh, U.; Chugh, A.; Palle, V. P.; Mookhtiar, K. A.; Vacca, J.; Chakravarty, P. K.; Nargund, R. P.; Wright, S. D.; Roy, S.; Graziano, M. P.; Singh, S. B.; Cully, D.; Cai, T.-Q. ACS Med. Chem. Lett. 2011, 2, 919. http://dx.doi.org/10.1021/ml2001938

22. Imbriglio, J. E.; Coletti, S. L.; Tata, J. R.; Liang, R.; Raghavan, S.; Schmidt, D. R.; Smenton, A. R.; Chan, S. Y. PCT Int. Appl. WO 2006113150 A1, 2006; Chem. Abstr. 2006, 145, 455008.

23. Thomas, A. A.; De Meese, J. ; Le Huerou, Y.; Boyd, S. A.; Romoff, T. T.; Gonzales. S. S.; Gunawardana, I.; Kaplan, T.; Sullivan, F.; Condroski, K.; Lyssikatos, J. P.; Aicher, T. D.; Ballard, J.; Bernat, B.; DeWolf, W.; Han, M.; Lemieux, C.; Smith, D.; Weiler, S.; Wright, S. K., Vigers, G.; Brandhuber, B. Bioorg. Med. Chem. Lett. 2008, 18, 509. http://dx.doi.org/10.1016/j.bmcl.2007.11.098

24. Haddach, A. A.; Kelleman, A.; Deaton-Rewolinski, M. V. Tetrahedron Lett. 2002, 43, 399. http://dx.doi.org/10.1016/S0040-4039(01)02192-X

25. Pollock, P. M.; Cole, K. P. Org. Synth. 2012, 89, 537.

26. Elguero, J.; Marzin, C.; Katritzky, A. R. in Advances in Heterocyclic Chemistry, Suppl. 1: The Tautomerism of Heterocycles; Academic Press: New York, 1975, pp 313-336.

27. Minkin, V. I.; Garnovskii, A. D.; Elguero, J.; Katritzky, A. R.; Denisko, O. V. Adv. Heterocycl. Chem. 2000, 76, 157. http://dx.doi.org/10.1016/S0065-2725(00)76005-3

28. Krystof. V.; Cankar, P.; Frysová, I.; Slouka, J.; Kontopidis, G.; Dzubak, P.; Hajduch, M.; Srovnal, J.; de Azevedo, W. F. Jr.; Orság, M.; Paprskárová, M.; Rolcík, J.; Látr, A.; Fischer, P. M.; Strnad, M. J. Med. Chem. 2006, 49, 6500. http://dx.doi.org/10.1021/jm0605740

29. Braun, S.; Kalinowski, H.-O.; Berger, S. 150 and More Basic NMR Experiments: A Practical Course - Second Expanded Edition; Wiley-VCH: Weinheim, 1998. http://dx.doi.org/10.1002/nadc.19990470527

30. Alam, M.; Du Bois, D. J.; Hawley, R. C.; Kennedy-Smith, J.; Minatti, A. E.; Palmer, W. S.; Silva, T.; Wilhelm, R. S. US Patent 2011 0071150, 2011; Chem. Abstr. 2011, 154, 385113.

31. Aletru, M.; Aranyi, P.; Balogh, M.; Batori, S.; Bence, J.; Bovy, P.; Kapui, Z.; Mikus, E.; Namane, C.; Philippo, C.; Szabo, T.; Tomoskozi, Z.; Urban-Szabo, K. US Patent 2011 0059964, 2011; Chem. Abstr. 2005, 143, 11553. 